\title{
Occurrence, pathogenicity, and control of acanthocephalosis caused by Neoechinorhynchus buttnerae: A review
}

\author{
Ocorrência, patogenicidade, e controle de acantocefalose causada por \\ Neoechinorhynchus buttnerae: uma revisão
}

\author{
Liliane de Araújo Castro', Gabriela Tomas Jerônimo², Renata Maria da Silva³, Maria João Santos", \\ Cleverson Agner Ramos 5 , Sanny Maria de Andrade Porto ${ }^{2 *}$ (1)
}

\begin{abstract}
${ }^{1}$ Pós-graduanda do Programa em Ciências Pesqueiras nos Trópicos, Universidade Federal do Amazonas - UFAM, Manaus, AM, Brasil ${ }^{2}$ Laboratório de Sanidade de Animais Aquáticos - LASAA, Departamento de Ciências Pesqueiras, Universidade Federal do Amazonas UFAM, Manaus, AM, Brasil

${ }^{3}$ Programa de Pós-graduação em Aquicultura, Universidade Nilton Lins, Manaus, AM, Brasil

${ }^{4}$ Departamento de Biologia, Faculdade de Ciências, Universidade do Porto, Porto, Portugal

${ }^{5}$ Departamento de Morfologia, Instituto de Ciências Biológicas, Universidade Federal do Amazonas - UFAM, Manaus, AM, Brasil
\end{abstract}

How to cite: Castro LA, Jerônimo GT, Silva RM, Santos MJ, Ramos CA, Andrade-Porto SM de. Occurrence, pathogenicity, and control of acanthocephalosis caused by Neoechinorhynchus buttnerae: A review. Braz J Vet Parasitol 2020; 29(3): e008320. https:// doi.org/10.1590/S1984-29612020070

\begin{abstract}
Infections negatively influence the production of tambaqui, and in north Brazil, the wide distribution of this parasitic disease has generated concern among fish farmers. The objective of this study was to review published literature on this pathogen. Six main online research databases were searched using the keywords "Neoechinorhynchus buttnerae", "acantocefalose", and "acanthocephalan fish". Based on a set of predetermined criteria, 39 publications were selected for this review. The mechanism of pathogenic action of $\mathrm{N}$. buttnerae is related to the degree of penetration of the proboscis. Infection results in histopathological and morphological changes in the host. The recurrence of the parasite in the northern region was greater twelve years after their first occurrence. The lack of specific legislation on veterinary products for aquatic animals, combined with the neglect of good management practices, and the absence of a contingency plan for the control of acanthocephalan infections have contributed to the current health situation of Colossoma macropomum northern Brazil. Additional information about the occurrence of the disease, pathogenicity, and control of acanthocephalan infections are imperative for developing a disease contingency plan in the region and research to address these should be encouraged by the sector.
\end{abstract}

Keywords: Acanthocephala, life cycle, fish farm, tambaqui, treatment.

\begin{abstract}
Resumo
As infecções influenciam negativamente a produção de tambaqui e, no norte do Brasil, a ampla distribuição dessa doença parasitária tem gerado preocupação entre os piscicultores. O objetivo deste estudo foi revisar a literatura publicada sobre esse patógeno. Seis principais bancos de dados de pesquisa on-line foram investigados usando-se as palavras-chave "Neoechinorhynchus buttnerae", "acantocefalose" e "acantocéfalos de peixe". Com base em um conjunto de critérios predeterminados, 39 publicações foram selecionadas para esta revisão. 0 mecanismo de ação patogênica de $N$. buttnerae está relacionado ao grau de penetração da probóscide. A infecção resulta em alterações histopatológicas e morfológicas no hospedeiro. A recorrência do parasito na região Norte foi maior, doze anos após sua primeira ocorrência. A falta de legislação específica sobre produtos veterinários para animais aquáticos, combinada com a negligência de boas práticas de manejo e com a ausência de um plano
\end{abstract}

Received April 13, 2020. Accepted July 03, 2020

Financial support: Foundation Support of Research the State of Amazonas (FAPEAM) Process No. 062.00847.2019; Graduate Program in Fisheries Science in the Tropics, Federal University of Amazonas (UFAM) - PAPAC 005/2019; UFAM (041/2016). Coordination for the Improvement of Higher Education Personnel - Brazil (CAPES), National Academic Cooperation Program in the Amazon - PROCAD/Amazônia - Finance Code 001 (88881.200614 / 2018-01). National Council for Scientific and Technological Development (CNPq) process no. 131637/2018-5 and 402434/2016-1.

*Corresponding author: Sanny Maria de Andrade Porto. E-mail: sanny@ufam.edu.br 
de contingência para o controle de infecções por acantocéfalos, contribuíram para a atual situação sanitária em Colossoma macropomum na região Norte do Brasil. Informações adicionais sobre a ocorrência da doença, patogenicidade e controle de infecções por acantocéfalos são imprescindíveis para o desenvolvimento de um plano de contingência de doenças na região e pesquisas para resolvê-las devem ser incentivadas pelo setor.

Palavras chave: Acanthocephala, ciclo de vida, piscicultura, tambaqui, tratamento.

\section{Introduction}

Globally, the harvests from aquaculture have increased at an accelerated rate, with an average annual growth of $5.8 \%$. In 2016, world production reached approximately 110.2 million tons, fish farming corresponded to approximately 49\% of this total (FAO, 2018). In Brazil, production from fish farming in 2018 was 722,560 tons, with 4.5\% growth over the previous year. Tambaqui (Colossoma macropomum Cuvier, 1818) stood out as the main native species raised in captivity, and is produced in the main states of the northern, midwestern, and northeastern regions (Ribeiro et al., 2016; Peixe BR, 2019).

This prominence in tambaqui productivity is associated with the availability of juveniles throughout the year, their ability to survive during the most diverse types of management and production systems, excellent adaptation to commercial feed, great zootechnical potential, and good demand in the national and international consumer markets (Rodrigues, 2014; Ribeiro et al., 2016).

Despite these favorable characteristics, the production of tambaqui still presents challenges, especially those related to health issues involving parasites (Jerônimo et al., 2017; Lourenço et al., 2018; Pereira \& Morey, 2018). In Brazil, different groups of parasites have been identified in this species, such as protozoa, myxosporids, crustaceans, and helminths, which, when conditions are favorable, proliferate and cause diseases (Fujimoto et al., 2015; Jerônimo et al., 2017).

Among these, the metazoan of the acanthocephalan group Neoechinorhynchus buttnerae Golvan, 1956 stands out due to the numerous cases of infections in fish recorded in the northern region of Brazil (Chagas et al., 2015; Oliveira et al., 2015; Jerônimo et al., 2017; Pereira \& Morey, 2018). This parasite affects the tambaqui (Aguiar et al., 2018), and its hybrids namely, tambacu (Piaractus mesopotamicus $\times$ Colossoma macropomum) (Silva et al., 2013) and tambatinga (Colossoma macropomum $\times$ Piaractus brachypomus) (Dias et al., 2015), and causes concern to fish farmers since it affects the growth of the fish and thus results in low yields.

Physiological and histopathological studies of fish infected with acanthocephalans indicate that, in general, the inflammatory process is caused by the proboscis both at the site of attachment of the parasite and along the intestinal portions, which causes the shift of inflammatory cells to lesions (Sfacteria et al., 2015) and occlusion of the intestinal lumen when the intensity of infection is high (Sanil et al., 2011). Associated with these changes, acanthocephalan infections can cause anatomical changes such as changes in growth, weight loss, deformities in body mass, and also mortality of the hosts (Amin et al., 2017). This has financial impacts, since the presence of the parasite in farmed fish can trigger decreased income and increased production costs (Gomes et al., 2017).

Hence, the objective of this study was to review the available information on the occurrence of acanthocephalan infections caused by N. buttnerae, its morphology and life cycle, pathogenicity, clinical signs, and the use of chemotherapy and herbal medicines for controlling it.

\section{Materials and Methods}

For the preparation of this review article, were used literature published between 1950 to 2019, the following databases were consulted: CAPES Journals, Google Scholar, Scopus, Web of Science, Scielo, and Science Direct. In addition, Google Books and printed editions of technical manuals were also searched. In view of the diffuse nature of the research, the following keywords were used "Neoechinorhynchus buttnerae", "acantocefalose", and "acanthocephalan fish".

In order to select publications for this review, it was necessary to adopt some criteria for the inclusion of the most pertinent articles. The selection criteria were 1) occurrence of acanthocephalans in fish, 2) consequences resulting from infections caused by acanthocephalans, and 3) herbal and chemotherapeutic treatments to control acanthocephalans in fish. Since they did not conform to these criteria, 155 of the 195 publications found were excluded and the remaining 40 publications were used as a theoretical framework for this review article. 


\section{History of the occurrence of Neoechinorhynchus buttnerae in farmed fish}

The first record of $N$. buttnerae occurrence in Brazil was in tambaqui that weighed approximately $100 \mathrm{~g}$ in a fish farm producing fry to supply fattening farms in the state of Amazonas, Brazil. In this case, Malta et al. (2001) observed $100 \%$ prevalence, with an average intensity of 125.26 parasites per host, which attributed to fish mortality. Unfortunately, due attention was not paid to this outbreak. Additionally, a lack of a plan to prevent the spread of the pathogen has resulted in the recurrence of the infection over the years.

Seven years later, in a simple report on parasitosis in the same location as the previous episode, Chagas et al. (2015) observed new cases in tambaqui fry $(n=800)$, which died after being transported. As of 2013 , infections have recurred. Silva et al. (2013), while verifying the fauna parasite of tambacu in four fish farms in Macapá, state of Amapá, Brazil, recorded the first case of N. buttnerae in this hybrid fish, with a prevalence of $12.5 \%$ and an average intensity of 18.5 parasites per host in fish weighing between 408-2078 g. Later, in the same state, Dias et al. (2015) reported the occurrence of acanthocephalan in the hybrid tambatinga. In 2015, there was another incidence of the parasite, this time in the state of Rondônia, Brazil. Despite the low percentage of parasitism in tambaquis, Oliveira et al. (2015) reported the presence of $N$. buttnerae in farmed fish from six locations in the Jamari Valley, in the state of Rondônia.

Since then, reports of $N$. buttnerae in fish farms have become increasingly common, especially in the northern region of Brazil, and it is already notable that this parasite has become a problem for production. Thus, Gomes et al. (2017) assessed the impact of infections on the zootechnical and economic performance of tambaqui and observed that massive acanthocephalan infection can affect fish growth by up to $200 \%$, directly affecting the gross revenue. This shows a difference of $>1000 \%$ in revenue earned between farms with infected fish and those with parasite-free fish.

Other studies with new reports of occurrences as well as those that sought to understand the mechanism of parasitism have emerged. Jerônimo et al. (2017) evaluated the pathology caused by $N$. buttnerae in tambaqui from fish farms with different levels of infection located in the municipality of Cujubim, state of Rondônia, and Manaus, state of Amazonas. Both study areas showed $100 \%$ prevalence. In Rondônia, the fish had an average intensity of 262.7 parasites in sub-adult fish weighing about $250 \mathrm{~g}$ and adults weighing $2 \mathrm{~kg}$. In the fish farms evaluated in the state of Amazonas, the fish had an average intensity of 476.8 parasites in adult fish weighing 800 g. Further, Matos et al. (2017) reported high levels of infection by acanthocephalans in fish farms in Manaus, Amazonas, as early as 2013. The authors also analyzed the morphological and histochemical changes associated with high infection by $N$. buttnerae. In the same state, Lourenço et al. (2017) recorded the occurrence of $N$. buttnerae in tambaqui raised in the municipality of Rio Preto da Eva, and found a prevalence of $100 \%$ and an average intensity of 347.5 parasites in fish that weighed, on an average, $148.74 \mathrm{~g}$. These reports are warning signs for fish farmers of the possible damage that this parasite can cause.

Subsequently, Aguiar et al. (2018) evaluated the histopathological damage caused by N. buttnerae in the intestine of tambaqui using semi-quantitative analysis. There was a prevalence of $100 \%$ and an average intensity of 143.3 parasites in fish weighing $2.69 \mathrm{~g}$ from a fish farm in Manaus, state of Amazonas. Pereira \& Morey (2018) recorded the first case of $N$. buttnerae in tambaqui raised in the state of Roraima, and reported loss of body mass in fish weighing $360 \mathrm{~g}, 100 \%$ prevalence, and an average intensity of 269.48 parasites per host. These findings corroborate those of Chagas et al. (2019), who, when evaluating parasitism caused by N. buttnerae in tambaqui raised in Rio Preto da Eva, state of Amazonas, noticed that the acanthocephalans negatively interfered with the condition of the animals.

Thus, we can infer that the parasite can affect different size classes, with different consequences, but, in most situations, this infection will culminate in economic losses. It is also evident that the distribution of this parasite is concentrated in the fish farms in the north, especially in the state of Amazonas.

It is worth mentioning that this parasite was described in 1956 by Golvan (1956) in fish collected from their natural environments. Possibly, their introduction into fish farms may have been a result of supplying aquaculture enterprises with waters containing the intermediate hosts of this parasite, or supplying breeders that were already infected. In the following section, we will detail how, in both a natural environment and in fish farms, when conditions are favorable, the proliferation of $N$. buttnerae is completely viable.

\section{Morphology and life cycle}

Acanthocephalans belong to the phylum Acanthocephala are characterized by their elongated cylindrical bodies. Their color may be white, yellowish, or orange, varying according to the intestinal content of the host (Bush et al., 2001; Sanil et al., 2011). They have a retractable proboscis with hooks curved at its anterior end, the function of 
which is to help the parasite attach to the intestinal wall of the definitive host (Van Cleave, 1952; Nicholas, 1973). In N. buttnerae, this proboscis is considered small when compared to its body size, and is composed of three types of hooks, large upper and medium and small lower hooks, responsible for their attachment to the host's tissues (Amin \& Heckmann, 1992; Ishikawa et al., 2016; Thatcher, 1981).

These parasites show sexual dimorphism-females have a genital orifice (gonopore) at the posterior end and are larger, while the male has a copulatory bursa at its posterior end (Malta et al., 2001; Matos et al., 2017; Travassos, 1950). Both sexes have pores and channels throughout the body indicating that nutrients are absorbed by the integument, through direct contact of the parasite with the intestinal mucus of the host (Bush et al., 2001; Nicholas, 1973; Núñez \& Drago, 2017; Sanil et al., 2011; Travassos, 1950). Like other acanthocephalan species, N. buttnerae has heteroxenic life cycle.

Lourenço et al. (2018) described the biological cycle of this parasite, which included an intermediate host, the ostracod Cypridopsis vidua Müller, 1776. The following stages of development were observed during the parasites lifecycle: egg, with three membranes covering the acanthus larva; twenty-four hours after ingestion of eggs by intermediate host, turn acanthor phase; nine days after in acanthella that increases in size and thirteen days after ingestion of egg, the invaginated proboscis starts to become more evident, and lemniscus begins to form, the proboscis receptacle is almost formed, and the sexual organs begin to take shape; then turning into cystacanth, considered the final immature stage, characterized by the formation of an infectious cyst. After this phase, the parasite begins to grow inside the intestine of C. macropomum until maturity, and completes its life cycle.

As a parasitic strategy, the authors claim that the infected ostracods, despite having benthic habits, swim on the surface of the experimental units. Thus, as the definitive host (C. macropomum) is a filter feeder, it has the greatest chance of preying on the ostracods, resulting in the $N$. buttnerae reaching its reproductive phase. After the intermediate host along with the infective form of the parasite is ingested by the fish, the acanthocephalan takes about four to eight weeks to release the eggs along with the feces of the definitive host. Therefore, it is possible to infer that the life cycle of this acanthocephalan can vary from four to twelve weeks.

\section{Pathogenicity and clinical signs}

The pathogenicity varies according to the proboscis penetration depth, which may cause damage to the different tissue layers of the intestine (mucosa, submucosa, muscular, and serous) (Dezfuli et al., 2002; Kabata, 1985). Histopathological studies of acanthocephalan infections in fish indicate the development of local and generalized inflammation in the digestive tract, reducing the migration of various inflammatory cells to the site of infection (Sfacteria et al., 2015).

In the case of $N$. buttnerae, although its proboscis is relatively short, it can reach all layers of the intestinal wall (Aguiar et al., 2018; Jerônimo et al., 2017; Matos et al., 2017). However, parasites are most often seen unhindered in the lumen, forming nodules, due to agglomeration at high levels of infection (Aguiar et al., 2018; Gomes et al., 2017).

The degree of penetration of the proboscis of $\mathrm{N}$. buttnerae into the intestinal mucosa can cause histopathological changes in the intestine of the host, such as obstruction of the intestinal lumen, metaplasia, lesions of the epithelium, destruction of the villi, granulomatous reactions, and, in severe cases, peritonitis, intense hemorrhage, and necrosis of the epithelium (Aguiar et al., 2018; Jerônimo et al., 2017; Lourenço et al., 2018; Matos et al., 2017). When high levels of infections occur, parasites can cause partial occlusion of the digestive tract of the definitive host and interfere with the absorption of nutrients (Jerônimo et al., 2017), which can cause the death of the fish (Jerônimo et al., 2017; Malta et al., 2001).

Neoechinorhynchus buttnerae infections can cause morphological changes in parasitized individuals, such as cachexia, growth retardation, body deformation, head size disproportionate to the body, flattening of the dorsal region due to loss of mass, decreased mucus production, and skin opacity (Gomes et al., 2017; Jerônimo et al., 2017; Malta et al., 2001). The occurrence of these clinical signs can make commercialization unfeasible and cause financial impacts to the tambaqui production chain.

According to Kabata (1985) and Gomes et al. (2017), unlike other parasitic diseases that cause loss of appetite and high mortality rates, fish infected with acanthocephalans show no signs of anorexia. Thus, due to the lack of knowledge regarding fish health, fish farmers continue to provide feed, but there is a reduction in feed conversion efficiency, which increases production costs (Gomes et al., 2017). 


\section{Use of chemotherapy and herbal medicines}

In Brazilian fish farming, the damage caused by pathogens has become an increasing concern, since the occurrence of diseases can interfere with the efficiency of feed conversion and consequently reflect on the productive performance of animals (Tavares-Dias \& Martins, 2017). In an attempt to minimize these impacts on the production cycle, fish farmers use products that are either unauthorized by the Ministry of Agriculture, Livestock and Supply (MAPA), or off-label use, in order to control these pathogens (Pádua, 2016), which can be considered negligent behavior (Corral et al., 2018).

In Brazil, the only antiparasitic medicine registered for use in fish is Masoten ${ }^{\circledR}$, which is recommended only for use against ectoparasites. However, further research on the use of products to control $\mathrm{N}$. buttnerae has been carried out. Orsi (2015) used mebendazole orally at concentrations of 0.5 g/kg, $1.0 \mathrm{~g} / \mathrm{kg}, 1.5 \mathrm{~g} / \mathrm{kg}$, and $2.0 \mathrm{~g} / \mathrm{kg}$, but it to be ineffective. Costa (2018) evaluated the application of essential oils from mint (Mentha piperita), lemon balm (Lippia alba), and ginger (Zingiber officinale) in in vitro tests, and obtained high efficacy and positive results in the concentration of $0.54 \mathrm{~g} / \mathrm{kg}$ for mint. Santos et al. (2018) investigated the in vitro efficacy of four essential oils, and Piper hispidinervum showed higher parasite mortality for a shorter exposure time. Oliveira et al. (2019) evaluated the in vitro efficacy of eight anthelmintic products, where $100 \mathrm{mg} / \mathrm{L}$ of emamectin benzoate, $300 \mathrm{mg} / \mathrm{L}$ of levamisole, $4.500 \mathrm{mg} / \mathrm{L}$ of ivermectin, and $2.500 \mathrm{mg} / \mathrm{L}$ of praziquantel were shown to be effective. Despite these promising results, studies are needed to assess the pharmacokinetics and pharmacodynamics of these products, in addition to the impact of the costs of implementing medications in fish feed, and the effects of the drug on the palatability of a medicated diet for tambaqui.

\section{Conclusions}

Although several recent studies have addressed acanthocephalan infections, there is a notable lack of information related to prevention, risk factors, and health emergencies. More studies focusing on these aspects are needed because of the economic impacts of this parasite on tambaqui production systems in the region.

Given the numerous records of cases of acanthocephalan infections in the northern region of Brazil, which are sometimes associated with mortality, and the indiscriminate use of chemotherapeutic drugs to control them, it is necessary to establish preventive measures aimed at controlling acanthocephalan infections as well as develop a contingency plan for the disease, and establish actions in the face of health events.

\section{Acknowledgements}

The authors would like to thank Foundation Support of Research the State of Amazonas (FAPEAM) for the support Program for the publication of scientific articles - Process No. 062.00847.2019 - Support for the Graduate Program in Fisheries Science in the Tropics, Federal University of Amazonas (UFAM) - PAPAC 005/2019; the funding of the Young Doctors Project of the UFAM (041/2016); the Coordination for the Improvement of Higher Education Personnel - Brazil (CAPES) through the National Academic Cooperation Program in the Amazon - PROCAD/Amazônia - Finance Code 001 (88881.200614 / 2018-01); and to National Council for Scientific and Technological Development (CNPq) for master scholarship L.A. Castro (131637/2018-5) and financial support to G.T. Jerônimo (402434/2016-1).

\section{References}

Aguiar LS, Oliveira MIB, Matos LV, Gomes ALS, Costa JI, Silva GS. Distribution of the acanthocephalan Neoechinorhynchus buttnerae and semiquantitative analysis of histopathological damage in the intestine of tambaqui (Colossoma macropomum). Parasitol Res 2018; 117(6): 1689-1698. http://dx.doi.org/10.1007/s00436-018-5840-8. PMid:29602971.

Amin OM, Heckmann RA, Zargar UR. Description of a new quadrigyrid acanthocephalan from Kashmir, with notes on metal analysis and histopathology, and a key to species of the subgenus Acanthosentis from the Indian subcontinent. J Parasito/ 2017; 103(5): 458-470. http://dx.doi.org/10.1645/17-27. PMid:28589837.

Amin OM, Heckmann RA. Description and pathology of Neoechinorhynchus idahoensis n. sp. (Acanthocephala: Neoechinorhynchidae) in Catostomus columbianus from Idaho. J Parasitol 1992; 78(1): 34-39. http://dx.doi.org/10.2307/3283682. PMid:1738067.

Associação Brasileira da Piscicultura - Peixe BR. Anuário Peixe BR da piscicultura. Info [online]. 2019 [cited 2020 Mar 11]. Available from: https://www.peixebr.com.br/Anuario2019/AnuarioPeixeBR2019.pdf 
Bush AO, Fernández JC, Esch GW, Seed JR. Acanthocephala: the thorny headed worms. In: Bush AO, Fernández JC, Esch GW, Seed JR, editors. Parasitism: The diversity and ecology of animal parasites. Cambridge: Cambridge University Press; 2001. p. 1970214.

Chagas EC, Maciel PO, Pereria SLA. Infecções por acantocéfalos: um problema para a produção de peixes. In: Tavares-Dias M, Mariano WS. Aquicultura no Brasil: novas perspectivas. 1st ed. São Carlos: Pedro \& João; 2015. p. 305-328.

Chagas EC, Pereira SLA, Benavides MV, Brandão FR, Monteiro PC, Maciel PO. Neoechinorhynchus buttnerae parasitic infection in tambaqui (Colossoma macropomum) on fish farms in the state of Amazonas. Bol Inst Pesca 2019; 45(2): e499. http://dx.doi. org/10.20950/1678-2305.2019.45.2.499.

Corral ACT, Queiroz MN, Andrade-Porto SM, Morey GAM, Chaves FCM, Araújo VLA, et al. Control of Hysterothylacium sp. (Nematoda: Anisakidae) in juvenile pirarucu (Arapaima gigas) by the oral application of essential oil of Piper aduncum. Aquaculture 2018; 494(1): 37-44. http://dx.doi.org/10.1016/j.aquaculture.2018.04.062.

Costa CMS. Viabilidade do cultivo in vitro de Neoechinorhynchus buttnerae (Acanthocephala) de Colossoma macropomum (Serrasalmidae) e seu controle in vitro e in vivo com óleos essenciais [dissertação]. Manaus: Universidade Nilton Lins; 2018.

Dezfuli BS, Giari L, Simoni E, Bosi G, Manera M. Histopathology, immunohistochemistry and ultrastructure of the intestine of Leuciscus cephalus (L.) naturally infected with Pomphorhynchus laevis (Acanthocephala). J Fish Dis 2002; 25(1): 7-14. http://dx.doi. org/10.1046/j.1365-2761.2002.00332.x.

Dias MKR, Neves LR, Marinho RGB, Pinheiro DA, Tavares-Dias M. Parasitism in tambatinga (Colossoma macropomum x Piaractus brachypomus, Characidae) farmed in the Amazon, Brazil. Acta Amaz 2015; 45(2): 231-238. http://dx.doi.org/10.1590/18094392201400974.

Food and Agriculture Organization of the United Nations - FAO. The State of World Fisheries and Aquaculture 2018: Meeting the sustainable development goals [online]. Rome, Italy: FAO; 2018 [cited 2020 Mar 11]. Available from: http://www.fao.org/documents/ card/en/c/I9540EN/

Fujimoto RY, Ishikawa MM, Iwashita MKP, Maciel PO, Benavides MV, Hide DMV, et al. Doenças parasitárias e manejo profilático de tambaquis (Colossoma macropomum) na região do Baixo São Francisco. Brasília: Embrapa Tabuleiros Costeiros; 2015.

Golvan YJ. Acanthocéphales d'Amazonie. Redescription d'Oligacanthorhynchus iheringi Travassos 1916 et description de Neoechinorhynchus buttnerae n. sp. (Neoacanthocephala-Neoechinorhynchidae). Ann Parasitol Hum Comp 1956; 31 (5-6): 500-524. http://dx.doi.org/10.1051/parasite/1956315500.

Gomes ALS, Coelho-Filho JG, Silva WV, Oliveira MIB, Bernardino G, Costa JI. The impact of Neoechinorhynchus buttnerae (Golvan, 1956) (Eoacanthocephala: Neochinorhynchidae) outbreaks on productive and economic performance of the tambaqui Colossoma macropomum (Cuvier, 1818), reared in ponds. Lat Am J Aquat Res 2017; 45(2): 496-500. http://dx.doi.org/10.3856/vol45-issue2fulltext-25.

Ishikawa MM, Jerônimo GT, Ventura AS, Pereira NL, Silva TSC, Zanon RB, et al. Parasitos de Peixes Redondos Produzidos na Região da Grande Dourados-MS: Características e possíveis soluções. Jaguariúna: Embrapa Meio Ambiente; 2016. (Série Documentos, 106).

Jerônimo GT, Pádua SB, Andrade Belo MA, Chagas EC, Taboga SR, Maciel PO, et al. Neoechinorhynchus buttnerae (Acanthocephala) infection in farmed Colossoma macropomum: A pathological approach. Aquaculture 2017; 469: 124-127. http://dx.doi.org/10.1016/j. aquaculture.2016.11.027.

Kabata Z. Diseases caused by worms-II-Nematoda and Acanthocephala. In: Kabata Z. Parasites and diseases of fish cultured in the tropics. London: Taylor \& Francis; 1985. p. 201-226.

Lourenço FS, Morey GAM, Malta JC. The development of Neoechinorhynchus buttnerae (Eoacanthocephala: Neoechinorhynchidae) in its intermediate host Cypridopsis vidua in Brazil. Acta Parasitol 2018; 63(2): 354-359. http://dx.doi.org/10.1515/ap-2018-0040. PMid:29654667.

Lourenço FS, Morey GAM, Pereira JN, Malta JCO. Ocorrência de Neoechinorhynchus (Neoechinorhynchus) buttnerae Golvan, 1956 (Acantocephala: Neochinorhynchidae) em Colossoma macropomum (Cuvier, 1818) (Characiformes: Serrasalmidae) provenientes de uma piscicultura da Amazônia brasileira. Fol Amaz 2017; 26(1): 1-8. https://dx.doi.org/10.24841/fa.v26i1.414

Malta JCO, Gomes ALS, Andrade SMS, Varella AMB. Massive infestation by Neoechinorhynchus buttnerae Golvan, 1956 (Eoacanthocephala: Neochinorhynchidae) in young "Tambaquis" Colossoma macropomum (Cuvier, 1818) cultured in the Central Amazon. Acta Amaz 2001; 31(1): 133-143. http://dx.doi.org/10.1590/1809-43922001311143.

Matos LV, Oliveira MIB, Gomes AL, Silva GS. Morphological and histochemical changes associated with massive infection by Neoechinorhynchus buttnerae (Acanthocephala: Neoechinorhynchidae) in the farmed freshwater fish Colossoma macropomum Cuvier, 1818 from the Amazon State, Brazil. Parasitol Res 2017; 116(3): 1029-1037. http://dx.doi.org/10.1007/s00436-017-5384-3. PMid:28124738.

Nicholas WL. The Biology of the Acanthocephala. Adv Parasitol 1973; 11(1): 671-706. http://dx.doi.org/10.1016/S0065308X(08)60195-5. PMid:4601313. 
Núñez V, Drago FB. Phylum Acanthocephala. In: Drago FB. Macroparásitos: Diversidad Y Biología. Argentina: Universidad Nacional de la Plata; 2017. p. 112-125.

Oliveira LCD, Majolo C, Brandão FR, Farias CFS, Oliveira MIB, Santos WB, et al. Avermectins, praziquantel and levamisole have in vitro efficacy against Neoechinorhynchus buttnerae (Neoechinorhynchidae) in Colossoma macropomum: A Serrasalmidae from the Amazon. J Fish Dis 2019; 42(5): 765-772. http://dx.doi.org/10.1111/jfd.12980. PMid:30801739.

Oliveira SRKS, Bezeraa MVP, Belo MMAA. Study of the endoparasites in tambaquis, Colossoma macropomum, from fish farms of Jamari Valley, State of Rondônia. Enc Bios 2015; 11(21): 1026-1041.

Orsi TM. Eficácia do mebendazol no controle de Neoechinorhynchus buttnerae Golvan, 1956 (Eoacanthocephala: Neoechinorhynchidae) parasitos de Colossoma macropomum (Cuvier, 1818) (Osteichthyes: Characidae) na Amazônia Central [dissertação]. Manaus: Universidade Nilton Lins; 2015.

Pádua SB. Neoechinorhynchus buttnerae (Acanthocephala): verminose emergente empeixes redondos. Info [online]. Laguna, SC: Aquaculture Brasil; 2016 [cited 2016 Ago 01] Available from: http://www.aquaculturebrasil.com/coluna/26/neoechinorhynchusbuttnerae-acanthocephala:-verminose-emergente-em-peixes-redondos.htm.

Pereira JN, Morey GAM. First record of Neoechinorhynchus buttnerae (Eoacantocephala, Neochinorhynchidae) on Colossoma macropomum (Characidae) in a fish farm in Roraima, Brazil. Acta Amaz 2018; 48(1): 42-45. http://dx.doi.org/10.1590/18094392201702411.

Ribeiro FM, Freitas PVDX, Santos EO, Sousa RMS, Carvalho TA, Almeida EM, et al. Alimentação e nutrição de Pirapitinga (Piaractus brachypomums) e Tambaqui (Colossoma macropomum): revisão. Pubvet 2016; 10(12): 873882. http://dx.doi.org/10.22256/pubvet. v10n12.873-882.

Rodrigues APO. Nutrition and feeding of tambaqui (Colossoma macropomum). Bol Inst Pesca 2014; 40(1): $135-145$.

Sanil NK, Asokan PK, John L, Vijayan KK. Pathological manifestations of the acanthocephalan parasite, Tenuiproboscis sp. in the mangrove red snapper (Lutjanus argentimaculatus) (Forsskål, 1775), a candidate species for aquaculture from Southern India. Aquaculture 2011; 310(3-4): 259-266. http://dx.doi.org/10.1016/j.aquaculture.2010.10.027.

Santos WBS, Majolo C, Santos DS, Rosa MC, Monteiro PC, Rocha MJS, et al. Eficácia in vitro de óleos essenciais de espécies de Piperaceae no controle do acantocéfalo Neoechinorhynchus buttnerae. Rev Bras Hig Sanid Anim 2018; 12(4): 460-469. http://dx.doi. org/10.5935/1981-2965.20180042.

Sfacteria A, Brines M, Blank U. The mast cell plays a central role in the immune system of teleost fish. Mol Immuno/ 2015; 63(1): 3-8. http://dx.doi.org/10.1016/j.molimm.2014.02.007. PMid:24613788.

Silva RM, Tavares-Dias M, Dias MWR, Dias MKR, Marinho RGB. Parasitic fauna in hybrid tambacu from fish farms. Pesq Agropecu Bras 2013; 48(8): 1049-1057. http://dx.doi.org/10.1590/S0100-204X2013000800034.

Tavares-Dias M, Martins ML. An overall estimation of losses caused by diseases in the Brazilian fish farms. J Parasit Dis 2017; 41(4): 913-918. http://dx.doi.org/10.1007/s12639-017-0938-y. PMid:29114119.

Thatcher VE. Patologia de peixes da Amazônia brasileira. 1. Aspectos gerais. Acta Amaz 1981; 11(1): 125-140. http://dx.doi. org/10.1590/1809-43921981111125.

Travassos L. Introdução ao estudo da helmintologia. Rio de Janeiro: Edição da Revista Brasileira de Biologia; 1950.

Van Cleave HJ. Some host-parasite relationships of the Acanthocephala, with special reference to the organs of attachment. Exp Parasitol 1952; 1(3): 305-330. http://dx.doi.org/10.1016/0014-4894(52)90021-0. 